Article

\title{
Performance of Solar Absorption-Subcooled Compression Hybrid Cooling System for Different Flow Rates of Hot Water
}

\author{
Jinfang Zhang ${ }^{1,2,3}$, Zeyu Li ${ }^{1,2,3, *}$, Yue Jing ${ }^{1,2,3}$ and Yongrui $\mathrm{Xu}^{1,2,3}$ \\ 1 School of Electric Power, South China University of Technology, Guangzhou 510640, China; \\ 201720112923@mail.scut.edu.cn (J.Z.); 13719270169@163.com (Y.J.); xyrxuyongrui@163.com (Y.X.) \\ 2 Guangdong Province Key Laboratory of High Efficient and Clean Energy Utilization, South China \\ University of Technology, Guangzhou 510640, China \\ 3 Guangdong Province Engineering Research Center of High Efficient and Low Pollution Energy Conversion, \\ Guangzhou 510640, China \\ * Correspondence: epzeyuli@scut.edu.cn
}

Received: 11 December 2019; Accepted: 20 January 2020; Published: 23 January 2020

\begin{abstract}
The solar absorption-subcooled compression hybrid cooling system (SASCHCS) is tech-economically feasible for high-rise buildings. Since such a system operates with no auxiliary heat source, the performance coupling of its absorption subsystem and solar collectors is sensitive to the variation of hot water flow rate. In this regard, the relationship of system performance and hot water flow rate is required to be clarified exactly. Therefore, this paper aims to illustrate the effect mechanism of hot water flow rate and to propose the corresponding decision criterion. The case study is based on a typical high-rise office building in subtropical Guangzhou. The daily working process of this system with different hot water flow rates is simulated and analyzed. Subsequently, the useful heat of collectors and cooling capacity of the absorption subsystem with the hot water flow rate is discussed in detail. The results show that the SASCHCS operates with hot water temperatures ranging from $60{ }^{\circ} \mathrm{C}$ to $90^{\circ} \mathrm{C}$. The energy saving increases with the rise of hot water flow rate, but such variation tends to be flat for the excessively high flow rate. As the collector flow rate increases from $1 \mathrm{~m}^{3} / \mathrm{h}$ to $10 \mathrm{~m}^{3} / \mathrm{h}$, the daily energy saving improves by $21 \%$ in August. Similarly, the daily energy saving increases by $37.5 \%$ as generator hot water flow rate increases from $1 \mathrm{~m}^{3} / \mathrm{h}$ to $10 \mathrm{~m}^{3} / \mathrm{h}$. In addition, the collector flow rate of $3.6 \mathrm{~m}^{3} / \mathrm{h}\left(13.33\left(\mathrm{~kg} / \mathrm{m}^{2} \mathrm{~h}\right)\right)$ and the generator flow rate of 5.2 $\mathrm{m}^{3} / \mathrm{h}\left(19.26\left(\mathrm{~kg} / \mathrm{m}^{2} \mathrm{~h}\right)\right)$ are optimal for the annual operation, with considering power consumption of water pumps. This paper is helpful for the improvement of SASCHCS operating performance.
\end{abstract}

Keywords: hot water flow rate; solar cooling; absorption chiller; subcooled compression; hybrid system

\section{Introduction}

Recently, global warming has become a worldwide issue with the considerations of sustainable development. The Paris Climate Agreement approved in 2015 aims at limiting the global mean temperature rise to $2{ }^{\circ} \mathrm{C}$ in this century. To deal with the global warming, reducing the electricity consumption of refrigeration systems is essential and meaningful [1]. Given that the cooling demand of office buildings is often simultaneous to the available solar radiation, the solar cooling is considered as an effective solution to reduce the air conditioning energy consumption [2].

It was reported that absorption chillers account for $82 \%$ of the existing solar cooling plants because of their high performance and availability in the markets [3]. Nevertheless, they suffer from some economic obstacles, especially in the case of high-rise building applications. It is mainly attributed 
to insufficient collector installation areas and rather high cooling demand in these buildings. In this case, given that the specific collector area is as high as $4 \mathrm{~m}^{2} / \mathrm{kW}$ for single effect $\mathrm{LiBr} / \mathrm{H}_{2} \mathrm{O}$ absorption chillers [4], it is inferred that an auxiliary thermal source (e.g., gas-fired heaters) is necessary to provide supplementary heat. The resultant high fossil fuel consumption leads to the extremely high operation costs and poor economic profitability of such a solution [5]. Therefore, it is essential to propose an economically feasible solution for solar cooling in high-rise buildings.

To this point, different absorption-compression hybrid cooling systems, which employ conventional vapor compression chillers as their backup cooling devices, are proposed as alternatives. In the so-called parallel hybrid systems, chilled water is successively cooled in the evaporators of absorption and compression chillers [6]. It was found that, for such configurations, the payback period achieved 36.2 years without subsidies, which is $61.3 \%$ less than that of conventional solar cooling with a backup heat source [7]. In order to further enhance the economic feasibility of solar absorption-compression hybrid refrigeration for high-rise buildings, the solar absorption-subcooled compression hybrid cooling system (SASCHCS) was investigated by Li [8]. The notable characteristic of SASCHCS lies in the fact that the cooling capacity of the absorption subsystem serves as subcooling power for the compression subsystem [9]. Consequently, the performance of absorption chillers is enhanced, and more solar cooling power is produced. It is measured by an experiment in which $22.2 \%$ of compressor work is saved as compared to vapour compression chiller without subcooling on summer sunny days [10]. It was indicated that the payback period of SASCHCS is close to that of solar photovoltaic cooling (the most economical solution of solar cooling recently) [11]. Moreover, it was obtained that the absorption subsystem with a smaller size is appropriate for the thermo-economic design if the hot water temperature is less than $75^{\circ} \mathrm{C}$ [12].

It has been pointed out by $\mathrm{Qu}[13]$ that the constant-flow control strategies are appropriate for the low-grade solar thermal facility. Accordingly, the decision of collector flow rate is one of the critical issues regarding the SASCHCS, due to the heat input temperature of solar heat ranging from $60^{\circ} \mathrm{C}$ to $90{ }^{\circ} \mathrm{C}$. It was found that the heat convection coefficient of collectors goes up by $45.5 \%$ as the collector flow rate rises by $66.7 \%$ [14]. Hence, a higher collector flow rate is favorable for the thermal efficiency of collectors [15]. It was revealed that the solar thermal gain could be increased by $112.5 \%$ and the auxiliary energy consumption could be reduced by $75 \%$ as the collector flow rate grows from 100 $\mathrm{kg} / \mathrm{h}$ to $500 \mathrm{~kg} / \mathrm{h} \mathrm{[16]}$. Furthermore, the required collector area and storage tank volume come down by $3 \%$ and $16.7 \%$, respectively, when the collector flow rate grows by $42.9 \%$ [17]. In addition to the collector flow rate, it was obtained that the higher hot water flow rate of generators is beneficial for the cooling output of solar absorption chillers, i.e., the monthly cooling output increases by $13 \%$ as the flow rate goes up by four times [18]. Although solar cooling performance benefits from higher generator flow rates, the rapid consumption leads to the drop-off of heat quality. This means that an excessive generator flow rate is disadvantageous for operation of solar absorption cooling systems without auxiliary heat sources. Consequently, there is an optimal collector flow rate that maximizes the solar fraction [19]. It was derived that the optimal specific flow rate approaches to $30 \mathrm{~kg} /\left(\mathrm{h} \mathrm{m}^{2}\right)$ for solar single effect absorption chillers [4]. Similarly, the aforementioned optimal value maximizes the thermal efficiency of collectors as well [15]. Additionally, Iranmanesh [20] performed a global optimization for flow rates of the collector and generator by the genetic algorithm. Subsequently, Tzivanidis [21] pointed out that the appropriate ratio of the generator flow rate to the collector one is 1.15.

In the open literature, absorption cooling systems with auxiliary heat source are mainly investigated, and the effect of hot water flow rate on system performance is discussed. However, the corresponding operation guidelines are not fully appropriate for the SASCHCS, since its absorption subsystem is exclusively driven by solar energy. Given that there is a high temperature difference between the collector outlet and generator inlet in an absorption cooling system with an auxiliary heat source, its performance is relatively independent on the hot water flow rates of its collector or generator. Thus, the relationship of hot water flow rate in collectors/generators and performance of absorption subsystem/collectors are relatively weak. As for SASCHCS, the interaction effects between 
the collector and generator temperatures are more pronounced, so the operation characteristics of its collectors and absorption chiller are sensitive to the hot water flow rate. Thus, we attempt to study the relationship between the SASCHCS performance and hot water flow rate, and propose the decision guideline. In this work, a typical office building in subtropical Guangzhou and the local climate are considered for a case study. The daily operating processes of this system are simulated and compared under different hot water flow rate conditions. The optimal hot water flow rate of the collector and generator is obtained by genetic algorithm. The novelty of this paper is to explain the effect mechanism of hot water flow rate and present the corresponding decision criterion of SASCHCS. This paper is helpful for the improvement of system operation performance.

\section{Description of SASCHCS}

The schematic of SASCHCS is demonstrated in Figure 1. Such a hybrid system consists of three subsystems: the thermally-driven subsystem, absorption subsystem and compression subsystem. The collector and the storage tank are the evacuated tube collector (ETC) and stratified tank, respectively. The absorption subsystem is a single effect $\mathrm{LiBr} / \mathrm{H}_{2} \mathrm{O}$ chiller. The compression subsystem is a vapor compression chiller and its refrigerant is R410A. In the case of available solar energy, absorption subsystems provide the subcooling power of compression subsystem to save compressor work. In addition, the cooling load is solely covered by compression subsystem when the solar heat is insufficient to drive the absorption subsystem. The conversion of cooling output in the compression subsystem through the subcooling power mainly depends on the flow rate of cooling water and chilled water as well as the compressor speed [22]. It was exhibited that the increase of cooling capacity to the subcooling power is $0.9-1.2$ for the fixed superheating by experiment [23].

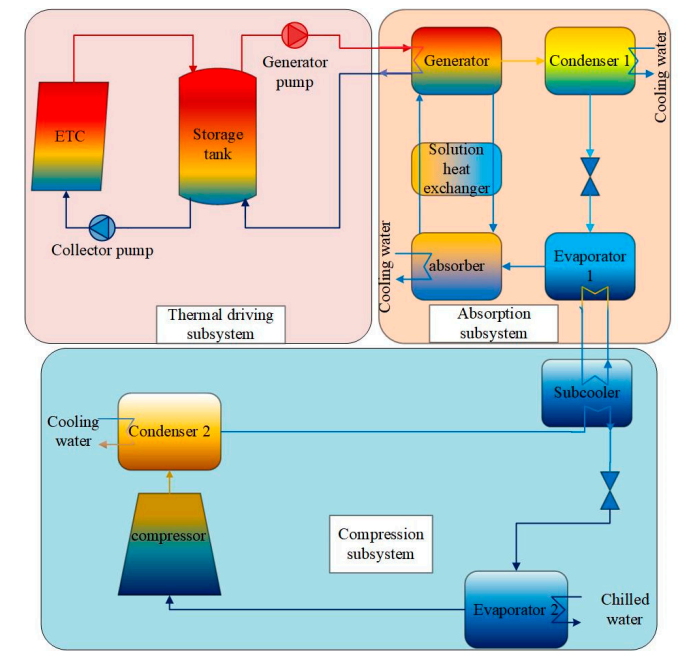

Figure 1. Schematic of solar absorption-subcooled compression hybrid cooling system (SASCHCS).

The collector pump is turned on at 8:00 a.m. and works with constant flow rate mode. It is switched off to avoid the crystallization of absorption subsystem as the top layer temperature of storage tanks exceeds $100{ }^{\circ} \mathrm{C}$. Subsequently, the collector pump restarts when the top layer temperature of storage tanks goes down to $95^{\circ} \mathrm{C}$. In addition, it is stopped as the collector outlet temperature is less than the bottom layer temperature of storage tanks.

The activation temperature of generator pump relies on the flow rate of generator hot water. It equals to $70{ }^{\circ} \mathrm{C}$ if the flow rate of generator hot water is lower than $3 \mathrm{~m}^{3} / \mathrm{h}$. In particular, the activation temperature of generator pump is $75^{\circ} \mathrm{C}$ when the flow rate of generator hot water is $1 \mathrm{~m}^{3} / \mathrm{h}$. Moreover, it equals to $65^{\circ} \mathrm{C}$ for other cases. It is noted that such adjustments of activation temperature are to not only guarantee the operation of absorption chillers but also enhance the chiller performance [24]. The 
generator pump operates with constant flow rate mode during the entire period. Furthermore, it is turned off if the outlet temperature of generator hot water is less than $55^{\circ} \mathrm{C}$.

\section{Model}

This section includes the modeling of SASCHCS and the model validation.

\subsection{Thermodynamic Model}

The thermodynamic model of SASCHCS is developed based on the following assumptions.

1. The operation of the hybrid system is considered as a quasi-static state.

2. The components of absorption subsystem and compression one are adiabatic.

3. The working fluids at the exit of evaporator and condenser in the compression subsystem are saturated.

4. There is no pressure loss in both the heat exchanger and pipeline.

5. The top layer temperature in the storage tank is equal to the generator inlet temperature.

6. The bottom layer temperature in the storage tank is equal to the collector inlet temperature.

Collector model:

The collector efficiency is calculated from the reference [15]:

$$
\eta=F_{R}\left[(\tau \alpha)-U_{L}\left(T_{c, i}-T_{a}\right) / I\right]
$$

The heat removal factor $F_{R}$ which relates the actual useful energy gain of a collector to the useful gain if the whole collector surface were at the fluid inlet temperature is defined as:

$$
F_{R}=\frac{m c_{p}}{A_{c} U_{L}}\left[1-\exp \left(-\frac{U_{L} F^{\prime} A_{c}}{m c_{p}}\right)\right]
$$

The overall heat loss coefficient $U_{L}$ is derived as below:

$$
U_{L}=U_{e}+U_{t}
$$

The edge loss coefficient of the header tube $U_{e}$ is expressed by:

$$
U_{e}=\frac{2 \pi \lambda_{\text {ins }}}{L_{T} \ln \left(D_{\text {ext }} / D_{\text {int }}\right)}
$$

The loss coefficient from the absorber tube to the ambient $U_{t}$ is expressed by:

$$
U_{t}=\frac{1}{\frac{1}{h_{g-a}}+\frac{1}{h_{p-g, r}+h_{p-g, c}}}
$$

Here, $h_{g-a}$ is the convection heat transfer coefficient, $h_{p-g, r}$ is the radiation heat transfer coefficient, and $h_{p-g, c}$ is the heat transfer coefficient due to the conduction. They are calculated by the expression of the reference [25].

The collector efficiency factor $F^{\prime}$ is also given by the reference [25]. $F^{\prime}$ represents the ratio of the actual useful energy gain to the useful gain that would result if the collector absorbing surface had been at the local fluid temperature:

$$
F^{\prime}=\frac{1 / U_{L}}{W\left[\frac{1+U_{L} / C_{b}}{U_{L}[d+(W-d) F]}+\frac{1}{C_{B}}+\frac{1}{h_{f} \pi d}\right]}
$$

Storage tank model: 
The energy balance of each layer with respect to the stratified storage tank is described as follows:

$$
\frac{1}{3} \rho V_{s t} c_{p} \frac{d T_{s t, i}}{d t}=\rho \dot{V_{c} c_{p}}\left(T_{s t, i-1}-T_{s t, i}\right)+\rho \dot{V}_{g} c_{p}\left(T_{s t, i+1}-T_{s t, i}\right)-h_{s t} A_{s t}\left(T_{s t, i}-T_{a}\right) / 3
$$

The energy change of the storage tank is equal to the heat generated by itself plus the incoming energy and the heat transfer between it and the environment. It is stated that the layer number rises in turn from top to bottom, i.e., layer 1 and layer 3 donate the top layer and bottom layer, respectively.

Absorption and compression subsystems model:

The off-design model of cooling subsystems (absorption and compression subsystems) was developed in our previous work based on the characteristic equations of the absorption subsystems and lumped parameter method of the compression subsystems [26].

The multiplication of area and heat transfer coefficient in generators for different flow rates of generator hot water is expressed as follows [27]:

$$
U A=\left(\frac{\dot{V}_{g}}{\dot{V}_{g, \text { rated }}}\right)^{0.8}(U A)_{\text {rated }}
$$

The cooling capacity of absorption subsystems is expressed below in terms of the model:

$$
Q_{e, a s}=s \cdot \Delta \Delta t-\alpha \cdot Q_{l o s s, a s}=s \cdot \Delta \Delta t-s \cdot \Delta \Delta t_{\min }
$$

$s$ accounts for the total amount of $U A$ spent in a building machine (but for the solution heat exchanger). $\alpha$ indicates how the distribution of the heat transfer capacity was done among the evaporator, absorber, generator and condenser. The parameter $\Delta \Delta t_{\text {min }}$ means a minimum thermodynamical driving force or a "friction loss" and is calculated as follows [28]:

$$
\Delta \Delta t_{\min }=1.9+0.1 \Delta \Delta t
$$

In the compression subsystem, the mass and energy conservation of component are described as follows:

$$
\begin{gathered}
\sum m_{i}=\sum m_{0} \\
Q=\sum m_{i} h_{i}-\sum m_{0} h_{o}=m c_{p} \Delta t=h \cdot A \cdot L M T D
\end{gathered}
$$

The compressor work is calculated:

$$
E=m\left(h_{d i s, s}-h_{s u c}\right) / \eta_{s}
$$

The daily useful heat of collectors equals:

$$
Q_{c}=\int_{\Delta t} m c_{p}\left(T_{c, o}-T_{c, i}\right) d t
$$

The daily cooling output of absorption subsystems is derived:

$$
Q_{e, a s}=\int_{\Delta t} m_{c h i, a s} c_{p}\left(T_{c h i, a s, i}-T_{c h i, a s, o}\right) d t
$$

The daily mean coefficient of performance (COP) of absorption subsystems is equal to:

$$
\mathrm{COP}=\frac{\int_{\Delta t} Q_{e, a s} d t}{\int_{\Delta t} Q_{g} d t}
$$


$Q_{g}$ is the generator energy and can be calculated by Equation (12). The daily energy saving of SASCHCS is defined as the difference of compressor work in the hybrid system and the one in the reference system:

$$
E_{\text {save }}=\int_{\Delta t}\left(E_{r e f}-E\right) d t
$$

Here, a traditional system is considered as the reference. By removing all the solar cooling devices, such a reference system simply consists a vapor compression chiller, satisfying the whole cooling load for buildings.

\subsection{Validation of Model}

The model is simulated in a MATLAB environment (R2018b, MathWorks, Natick, United States). Because the compound parabolic collector (CPC) is employed to feed absorption subsystems of SASCHCS prototype [10], the validation is divided into two sections. Firstly, the ETC model is verified by the experimental data from the reference [15]. The experiment is implemented at the College of Technological Studies, PAAET Kuwait. The collector flow rate was varied from $10 \mathrm{~kg} /\left(\mathrm{h} \mathrm{m}^{2}\right)$ to 60 $\mathrm{kg} /\left(\mathrm{h} \mathrm{m}^{2}\right)$. The comparison is exhibited in Table 1 and the maximal deviation is $6.3 \%$. Secondly, the modeling of SASCHCS is verified by the experiment data of the prototype [10] in the same condition. It is noted that the CPC is modeled in terms of the reference [29]. As shown in Figure 2, the simulation results are in good agreement with the measurement data, and the deviation is within $10 \%$. In addition, the simulation and experimental daily mean COP of the absorption subsystem are 0.594 and 0.567 , respectively. The deviation is only $4.8 \%$. The simulation and experimental daily mean COP of the compression subsystem are 6.59 and 6.41 , respectively. A good agreement is obtained.

Table 1. Validation of the ETC model.

\begin{tabular}{cccc}
\hline$\left(T_{c, i}-T_{a}\right) / I$ & Model & Experimental & Relative Error \\
\hline 0 & 0.68 & 0.69 & $1.4 \%$ \\
0.01 & 0.64 & 0.66 & $3.0 \%$ \\
0.02 & 0.61 & 0.62 & $1.6 \%$ \\
0.03 & 0.58 & 0.60 & $3.3 \%$ \\
0.04 & 0.55 & 0.57 & $3.5 \%$ \\
0.05 & 0.51 & 0.52 & $1.9 \%$ \\
0.06 & 0.48 & 0.50 & $4.0 \%$ \\
0.07 & 0.45 & 0.48 & $6.3 \%$ \\
0.08 & 0.41 & 0.42 & $2.4 \%$ \\
\hline
\end{tabular}

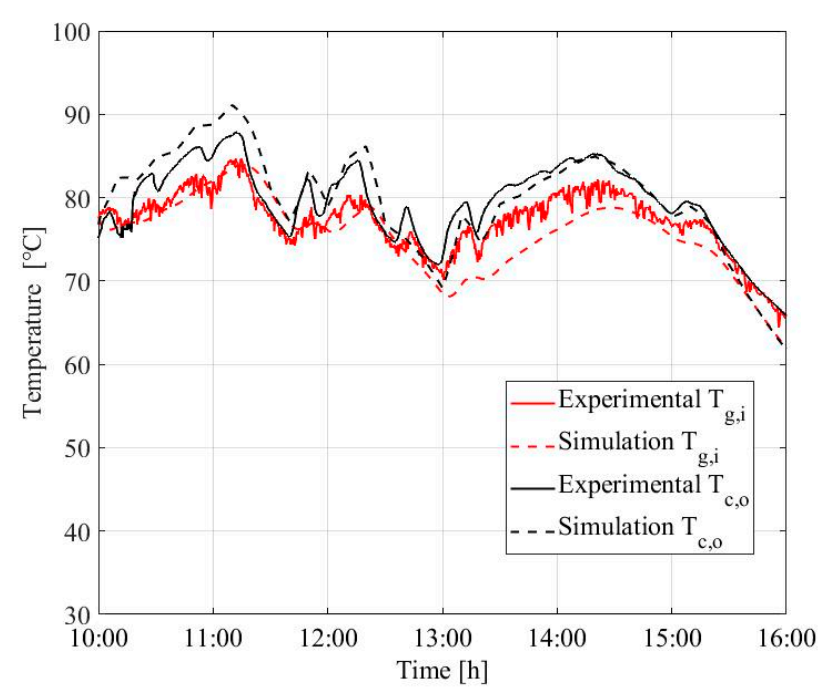

Figure 2. Validation of SASCHCS. 


\subsection{Case Study}

A typical office building located in subtropical city Guangzhou is considered. There are ten floors in this building. The area of each floor is $384 \mathrm{~m}^{2}$ so that the total area is $3840 \mathrm{~m}^{2}$. Furthermore, the heat transfer coefficient of wall, window and roof is $1.081 \mathrm{~W} /\left(\mathrm{m}^{2} \mathrm{~K}\right), 2.7 \mathrm{~W} /\left(\mathrm{m}^{2} \mathrm{~K}\right)$ and $0.812 \mathrm{~W} /\left(\mathrm{m}^{2}\right.$ $\mathrm{K})$, respectively. The daily cooling period spans from 8:00 a.m. to 6:00 p.m. The cooling season is from April to October. The hourly cooling demand is calculated by the DeST software [30]. The annual data are displayed in Figures 3-5. It should be mentioned that the meteorological data is the monthly mean values from the reference [31]. The design and operation condition of SASCHCS used in the above-mentioned office building is listed in Table 2. It should be mentioned that the initial temperature of the storage tank is equal to the ambient temperature, and the simulation time step is set to $1 \mathrm{~min}$. In addition, the thermodynamic properties of water and R410A are calculated by the software Refprop9 [32].

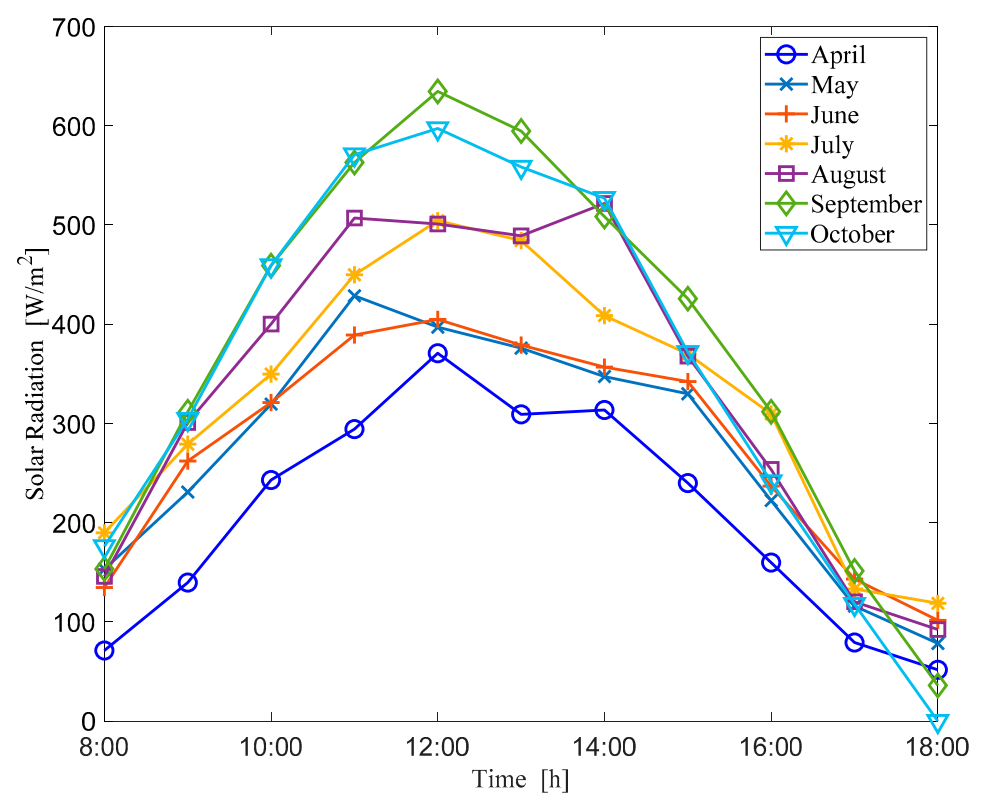

Figure 3. Solar radiation.

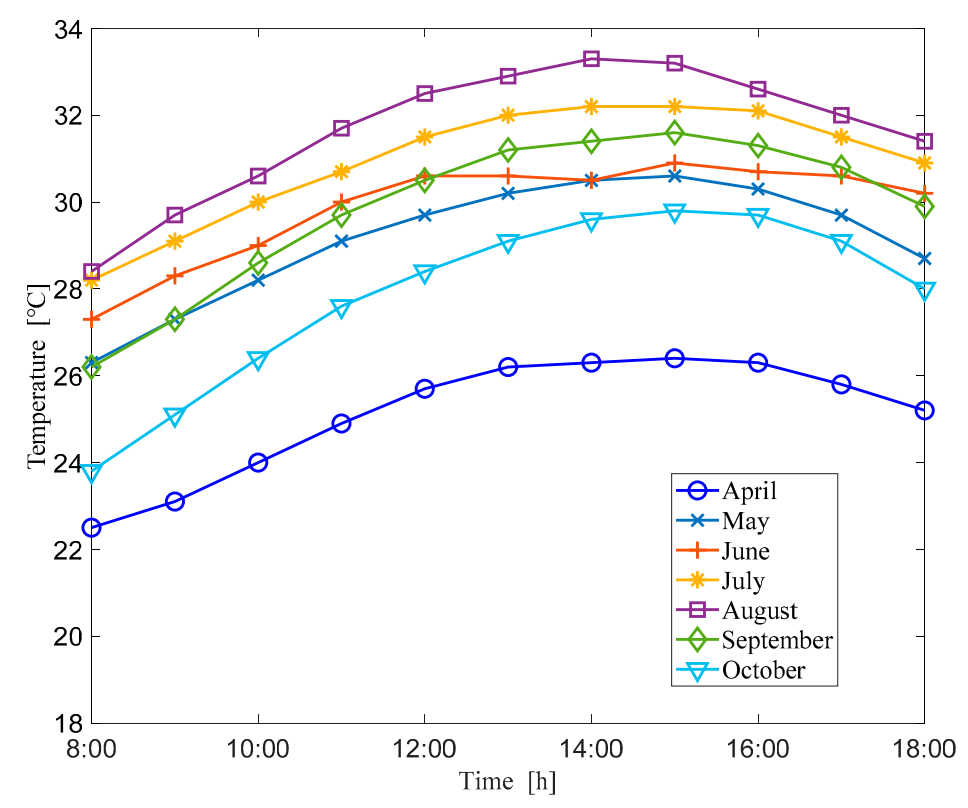

Figure 4. Ambient temperature. 


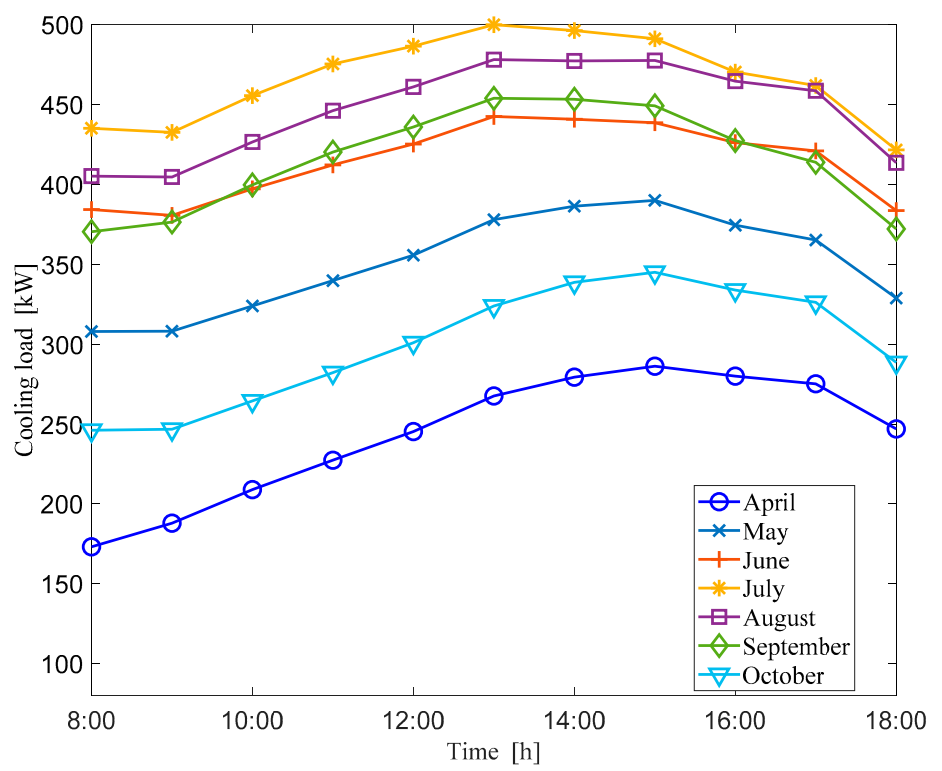

Figure 5. Cooling load.

Table 2. Design and operation parameters of SASCHCS.

\begin{tabular}{|c|c|c|c|}
\hline \multicolumn{2}{|c|}{ Parameters } & Unit & Value \\
\hline \multicolumn{4}{|c|}{ ETC } \\
\hline \multicolumn{2}{|c|}{ Aperture area of ETC } & $\mathrm{m}^{2}$ & 270 \\
\hline \multirow{2}{*}{ Absorber tube } & Outer diameter & $\mathrm{m}$ & 0.037 \\
\hline & Thickness & $\mathrm{m}$ & 0.0012 \\
\hline \multirow{2}{*}{ Glass tube } & Outer diameter & $\mathrm{m}$ & 0.047 \\
\hline & Thickness & $\mathrm{m}$ & 0.0012 \\
\hline \multicolumn{2}{|c|}{ Outer diameter of U-tube } & $\mathrm{m}$ & 0.008 \\
\hline \multicolumn{2}{|c|}{ Thickness of air layer } & $\mathrm{m}$ & 0.001 \\
\hline \multicolumn{2}{|c|}{ Thickness of copper fin } & $\mathrm{m}$ & 0.0006 \\
\hline \multirow{2}{*}{\multicolumn{3}{|c|}{$\begin{array}{c}\text { Length of the header pipe per one U-tube } \\
\text { Titled angle }\end{array}$}} & 1.2 \\
\hline & & & 20 \\
\hline \multicolumn{4}{|c|}{ Storage tank } \\
\hline \multicolumn{3}{|c|}{ Aspect ratio } & 3.5 \\
\hline \multicolumn{2}{|c|}{ Heat loss coefficient } & $\mathrm{W} /\left(\mathrm{m}^{2}{ }^{\circ} \mathrm{C}\right)$ & 0.83 \\
\hline \multicolumn{2}{|c|}{ Volume of storage tank } & $\mathrm{m}^{3}$ & 2.7 \\
\hline \multicolumn{4}{|c|}{ Absorption subsystem } \\
\hline \multirow{3}{*}{\multicolumn{2}{|c|}{$\begin{array}{l}\text { Nominal cooling capacity } \\
\text { Cooling water flow rate in condenser } \\
\text { 1/absorber/subcooler } \\
\text { Inlet temperature of cooling water }\end{array}$}} & $\mathrm{kW}$ & 45 \\
\hline & & $\mathrm{m}^{3} / \mathrm{h}$ & $8 / 9 / 10.5$ \\
\hline & & ${ }^{\circ} \mathrm{C}$ & 32 \\
\hline \multicolumn{4}{|c|}{ Compression subsystem } \\
\hline \multicolumn{2}{|c|}{ Nominal cooling capacity } & $\mathrm{kW}$ & 500 \\
\hline \multicolumn{2}{|c|}{ Cooling water flow rate in condenser 2} & $\mathrm{~m}^{3} / \mathrm{h}$ & 98.1 \\
\hline \multicolumn{2}{|c|}{ Inlet/outlet temperature of chilled water } & ${ }^{\circ} \mathrm{C}$ & $12 / 7$ \\
\hline \multicolumn{2}{|c|}{ Inlet temperature of cooling water } & ${ }^{\circ} \mathrm{C}$ & 32 \\
\hline \multicolumn{2}{|c|}{ Isentropic efficiency of compressor } & $\%$ & 0.7 \\
\hline
\end{tabular}




\section{Results and Discussion}

In this section, the influence of hot water flow rate in collectors and generators on the performance of SASCHCS is analyzed thoroughly at first. It is noted that such analysis is mainly based on the August data. Subsequently, the flow rate of hot water is optimized based on the annual data by the genetic algorithm.

\subsection{Effect of Hot Water Flow Rate}

The hot water temperature of collector outlet and generator inlet for two collector flow rates are displayed in Figure 6. It is noted that the generator flow rate is $10 \mathrm{~m}^{3} / \mathrm{h}$. For the case in which the collector flow rate equals $3 \mathrm{~m}^{3} / \mathrm{h}$, it is seen that the collector outlet temperature is quadratic owing to the change of solar irradiance, i.e., it grows to $85.6^{\circ} \mathrm{C}$ in the midday and falls to $57.2^{\circ} \mathrm{C}$ at the end of the operation. In addition, the generator pump is on at 10:17 a.m. when the top layer temperature of the storage tank reaches the activation temperature by solar heat. The sudden drop of generator inlet temperature is caused by the insufficient solar heat of a storage tank. Similarly, the hot water temperature of generator inlet is also quadratic since it is primarily controlled by the collector outlet temperature. It is demonstrated that the peak generator inlet temperature is $73.1^{\circ} \mathrm{C}$. For the case in which the collector flow rate is $10 \mathrm{~m}^{3} / \mathrm{h}$, the collector outlet temperature comes down because of the decreased temperature difference caused by the improvement of collector flow rate. It is observed that the collector outlet temperature fall by nearly $10{ }^{\circ} \mathrm{C}$ as the collector flow rate goes up by $7 \mathrm{~m}^{3} / \mathrm{h}$. In addition, the mentioned temperature drop gradually diminishes with the reduction of solar irradiance. There is not a sudden drop of generator hot water temperature as the activation of generator pump delays by 6 min compared with low collector flow rate. This phenomenon is attributed to the fact that the amount of solar heat in a storage tank is far greater than the consumption of absorption chillers. Thereby, the hot water temperature of generator inlet rises approximately by $1.7^{\circ} \mathrm{C}$ as the collector flow rate grows from $3 \mathrm{~m}^{3} / \mathrm{h}$ to $10 \mathrm{~m}^{3} / \mathrm{h}$.

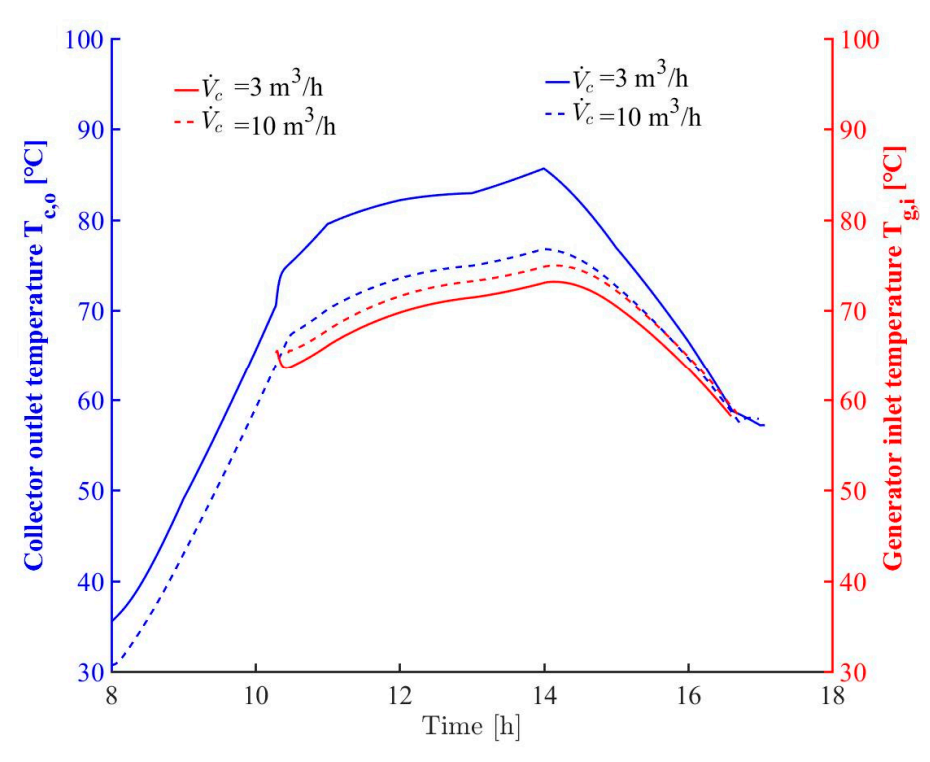

Figure 6. Hot water temperature for different $\dot{V}_{c}$.

The hot water temperature of the collector outlet and generator inlet for two flow rates of generator hot water are exhibited in Figure 7. It is mentioned that the collector flow rate equals $10 \mathrm{~m}^{3} / \mathrm{h}$. It is shown that the collector outlet temperature becomes lower for the enhanced flow rate of generator hot water due to the higher consumption of the absorption subsystem, as expected. The collector outlet temperature falls by around $7.0^{\circ} \mathrm{C}$ when the hot water flow rate of generator increases from $3 \mathrm{~m}^{3} / \mathrm{h}$ to $10 \mathrm{~m}^{3} / \mathrm{h}$. Simultaneously, the generator pump is on $17 \mathrm{~min}$ earlier as a result of the decrease of 
activation temperature. Nevertheless, the hot water temperature of the generator inlet goes down by about $7.6{ }^{\circ} \mathrm{C}$ for the hot water flow rate of a generator rising by $7 \mathrm{~m}^{3} / \mathrm{h}$.

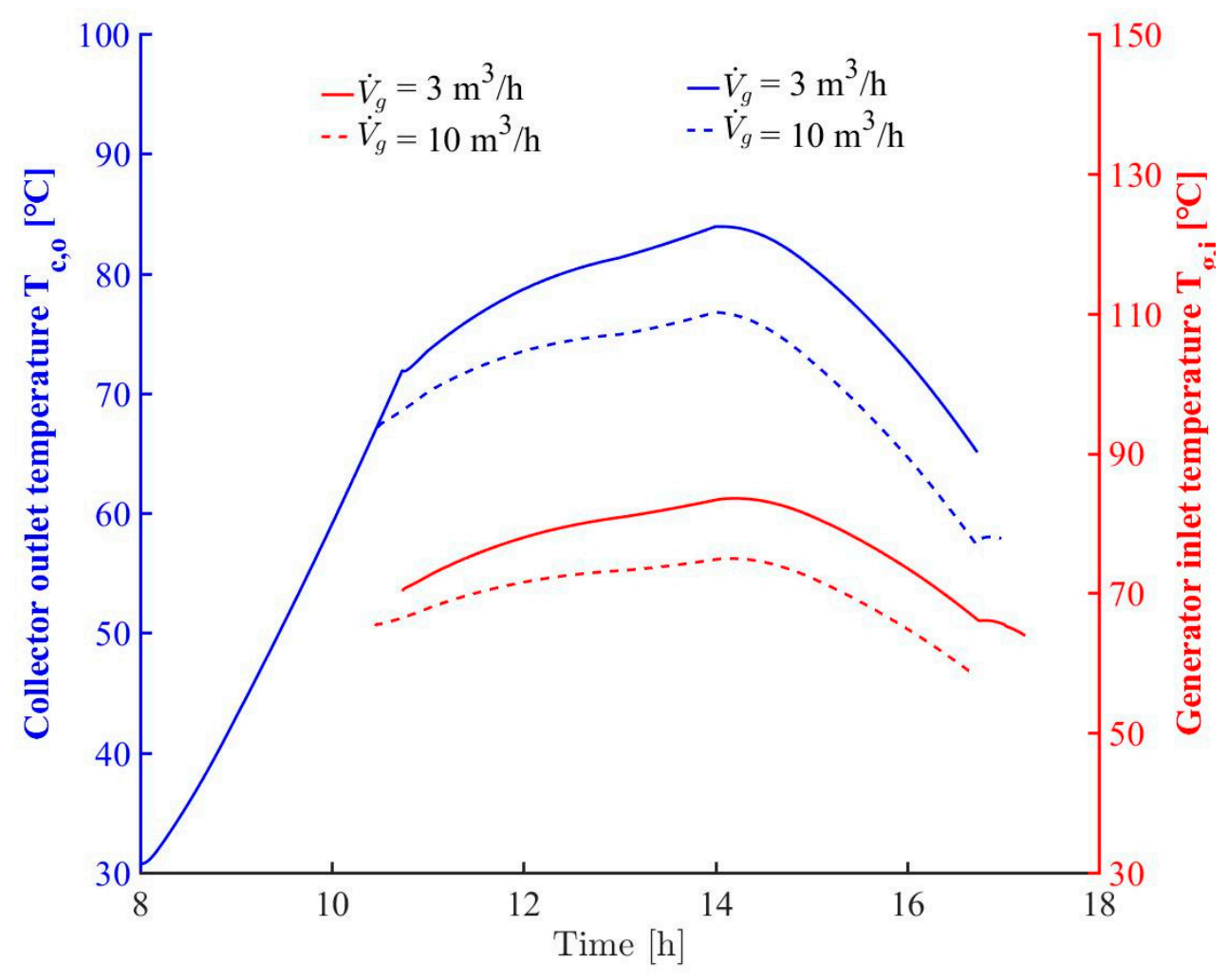

Figure 7. Hot water temperature for different $\dot{V}_{g}$.

The dependence of collector and absorption subsystem performance on a collector flow rate is displayed in Figure 8. Because the heat transfer coefficient enhances with the improvement of flow rate, the daily useful heat of collector goes up by $15.6 \%$ for the collector flow rate grows from $1 \mathrm{~m}^{3} / \mathrm{h}$ to $10 \mathrm{~m}^{3} / \mathrm{h}$. Additionally, such enhancement of solar heat becomes tiny when the collector flow rate exceeds $4 \mathrm{~m}^{3} / \mathrm{h}$, which is similar to conclusions of the reference [21]. It is explained by the insignificant growth of heat transfer coefficient with the flow rate in the turbulent flow region. On the other hand, the increase of generator hot water temperature leads to the weak effect of collector flow rate on the performance of absorption subsystem, i.e., the daily mean COP of absorption subsystem only goes up by $2.2 \%$ when the collector flow rate rises from $1 \mathrm{~m}^{3} / \mathrm{h}$ to $10 \mathrm{~m}^{3} / \mathrm{h}$. Accordingly, the daily cooling power of the absorption subsystem enhances by $22.5 \%$ due to the increasing solar heat and COP of the absorption chiller.

The influence of the hot water flow rate in generators is exhibited in Figure 9. Since the improvement of a generator hot water flow rate lowers the collector temperature, the enhanced thermal efficiency of collectors is beneficial for the amount of solar heat. It is shown that the daily useful heat of collectors grows by $23.9 \%$ for the generator flow rate rising from $1 \mathrm{~m}^{3} / \mathrm{h}$ to $10 \mathrm{~m}^{3} / \mathrm{h}$. However, the daily average COP of absorption chillers goes down by $12.4 \%$ simultaneously as a result of the decreased temperature of generator hot water. In general, the drop of COP in absorption subsystem is offset by the increase of solar heat, so that the daily cooling capacity of absorption subsystem goes up by $38.6 \%$ as the generator flow rate enhances from $1 \mathrm{~m}^{3} / \mathrm{h}$ to $10 \mathrm{~m}^{3} / \mathrm{h}$. It is noteworthy that such enhancement tends to be insignificant when the flow rate of generator hot water is higher than $6 \mathrm{~m}^{3} / \mathrm{h}$. By comparing Figure 8 with Figure 9, it can be seen that the performance of the collector as well as the absorption subsystem is more sensitive to the generator flow rate. Therefore, the suitable setting of generator flow rate is important for the efficient operation of SASCHCS. 


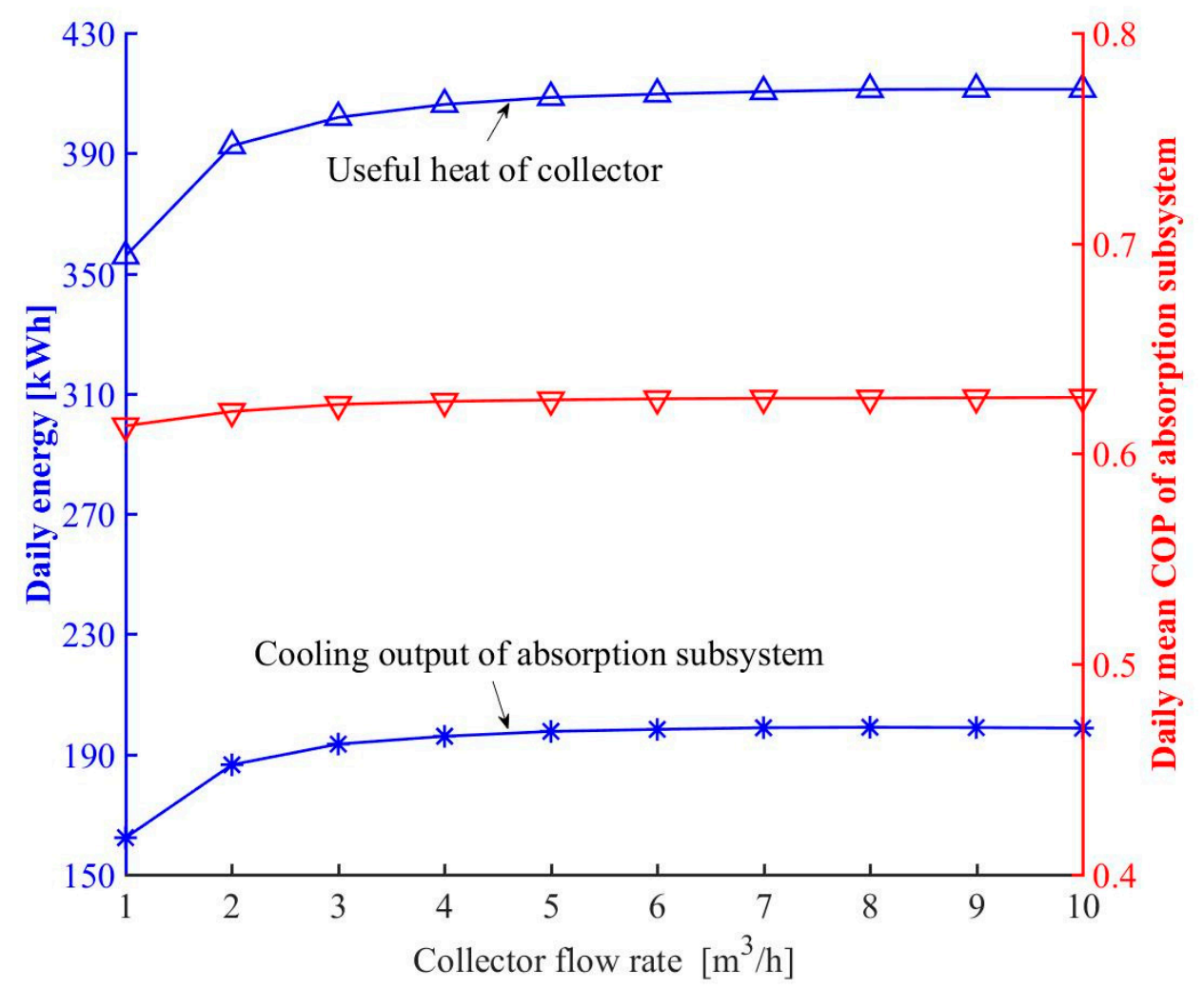

Figure 8. Impact of collector flow rate.

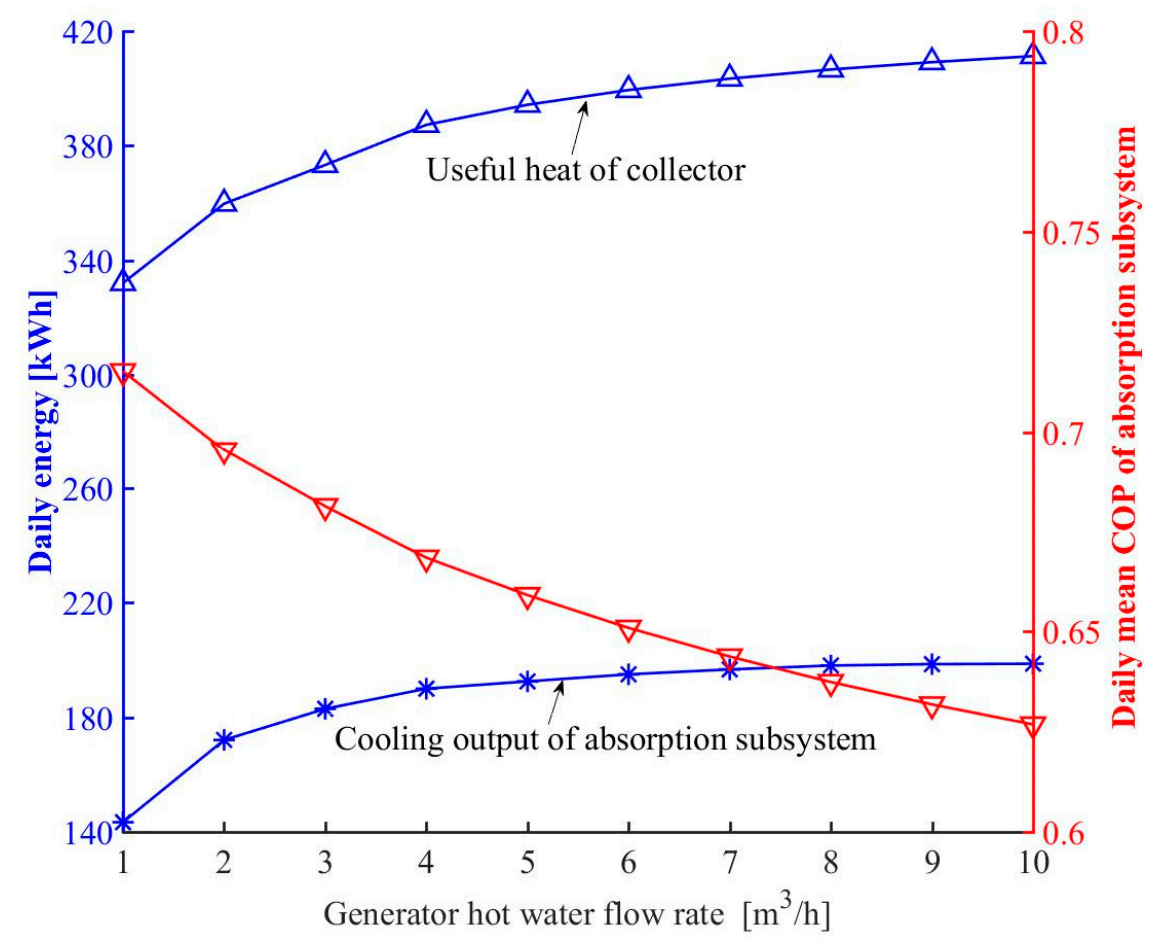

Figure 9. Impact of generator flow rate.

The daily energy saving of SASCHCS for different collector flow rates based on the data of from April to October is shown in Figure 10. As expected, the energy saving of the hybrid system is approximately coincident to the cooling output of the absorption subsystem with respect to the fact that it is mainly controlled by the latter. Furthermore, it is derived that the daily energy saving 
increased by $20-30 \%$ for the collector flow rate grows from $1 \mathrm{~m}^{3} / \mathrm{h}$ to $10 \mathrm{~m}^{3} / \mathrm{h}$. For example, the daily energy saving improvement based on the April, May, June, July, August, September and October data is $23.9 \%, 27.7 \%, 18.8 \%, 28.2 \%, 21 \%, 20.4 \%$ and $20.3 \%$, respectively.

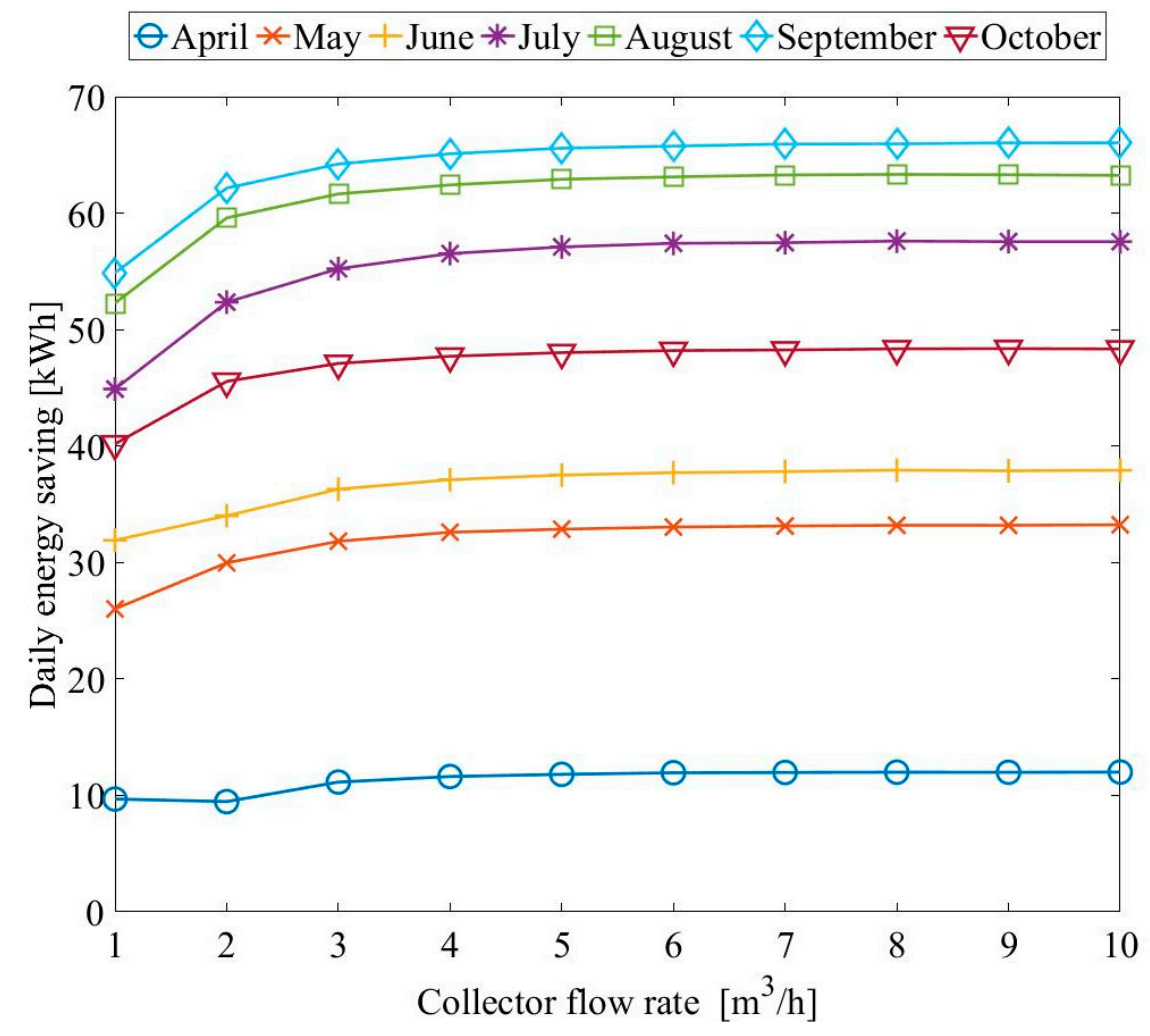

Figure 10. Daily energy saving for different collector flow rates based on the data from Apr to Oct.

The daily energy saving of SASCHCS for different generator hot water flow rates based on the data from April to October is demonstrated in Figure 11. It is observed that the energy saving gradually goes up with the growth of the generator hot water flow rate and tends to be flat finally. The daily saving of compressor work increases by $448 \%, 83.8 \%, 90.2 \%, 67.4 \%, 37.5 \%, 43.4 \%$ and $34.8 \%$, respectively, based on the data of April, May, June, July, August, September and October when the flow rate of generator hot water grows from $1 \mathrm{~m}^{3} / \mathrm{h}$ to $10 \mathrm{~m}^{3} / \mathrm{h}$. In the case of April to June, because the relatively high temperature of hot water $\left(>70^{\circ} \mathrm{C}\right.$ at least) is required for the operation of absorption subsystems at a low flow rate of generator hot water, the extremely short duration of absorption chillers caused by the weak solar irradiance leads to the excessively poor energy saving in $1 \mathrm{~m}^{3} / \mathrm{h}$ of a generator hot water flow rate. Consequently, the appropriate flow rate of generator hot water is highly important when the SASCHCS works with low solar irradiance. 
$\ominus$ April $*$ May + June $*$ July $\square$ August $\diamond$ September $\forall$ October

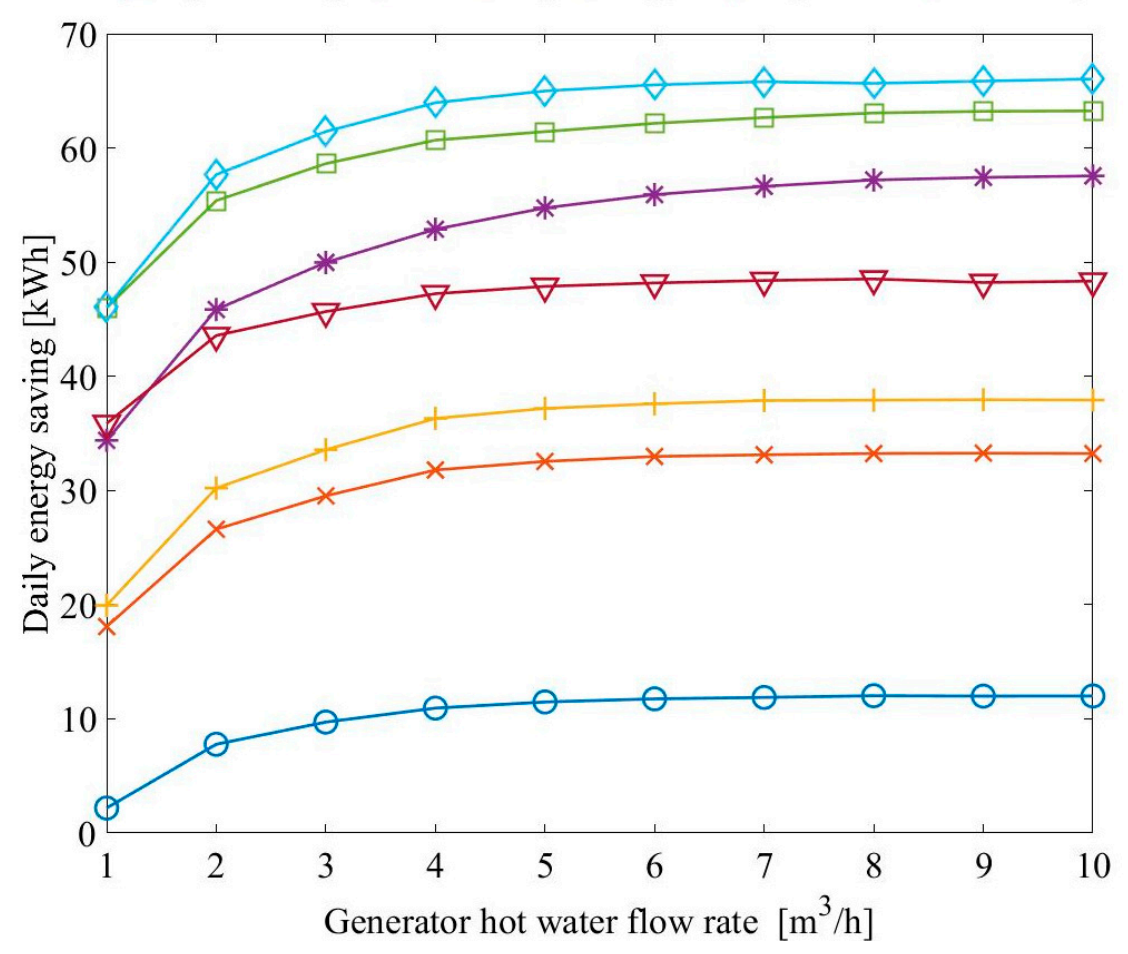

Figure 11. Daily energy saving for different generator flow rate based on data from Apr to Oct.

\subsection{Optimization of Hot Water Flow Rate}

According to the analysis of Section 4.1, it is known that the improvement of hot water flow rate is favorable for the energy saving of SASCHCS. However, it should be noted that the energy saving rises scarcely in addition to the growth of consumption in hot water pumps for the excessive increase of hot water flow rate. As a result, the collector and generator hot water flow rates are optimized based on the trade-off of energy saving and pump power, similar to Iranmanesh [20]. The power of hot water pumps is calculated by the reference [33]. Moreover, the optimization is implemented by the combination of the SASCHCS model and the module of a genetic algorithm in the MATLAB environment. The maximum generation number and population number are set as 50 and 20, respectively. The range of hot water flow rate is from $1 \mathrm{~m}^{3} / \mathrm{h}$ to $10 \mathrm{~m}^{3} / \mathrm{h}$. Furthermore, the maximum energy saving of hybrid systems is employed as the objective function. It is obtained that $3.6 \mathrm{~m}^{3} / \mathrm{h}\left(13.33 \mathrm{~kg} /\left(\mathrm{h} \mathrm{m}^{2}\right)\right)$ of a collector flow rate with $5.2 \mathrm{~m}^{3} / \mathrm{h}\left(19.26 \mathrm{~kg} /\left(\mathrm{h} \mathrm{m}^{2}\right)\right)$ of generator one is optimal for the annual operation of SASCHCS. The above-mentioned result implies that the generator hot water flow rate to the collector one approaches to 1.44 in the optimal case, which is slightly more than the ration gotten by Tzivanidis [21]. This difference is mainly attributed to the higher heat loss of ETC and the effect of month with low solar irradiance. On the other hand, the peak annual energy saving of SASCHCS in the optimal case is $8836.5 \mathrm{~kW} \mathrm{~h}$, which is equivalent to be $32.73 \mathrm{~kW} \mathrm{~h} / \mathrm{m}^{2}$ of specific ones.

\section{Conclusions}

The impact mechanism of hot water flow rate on the performance of SASCHCS is studied and the corresponding decision criterion is presented based on the annual data of a typical high-rise office building in subtropical Guangzhou. The primary findings are summarized below:

(1) The useful heat of collectors is beneficial for the increase of the collector flow rate due to the enhancement of heat transfer. Simultaneously, the improvement of amount in solar heat slightly increases the hot water temperature of generators and the consequent rise of COP in absorption subsystems. Therefore, the daily energy saving goes up by $21 \%$ based on the August data when 
the collector flow rate enhances from $1 \mathrm{~m}^{3} / \mathrm{h}$ to $10 \mathrm{~m}^{3} / \mathrm{h}$. It is noteworthy that such growth becomes tiny for the collector flow rate exceeding $4 \mathrm{~m}^{3} / \mathrm{h}$.

(2) Despite the increase of generator hot water flow rate decreasing the COP of absorption subsystems owing to the higher generator consumption, such drawback is offset by the enhanced amount of solar heat through the improvement of collector efficiency. Consequently, the daily energy saving grows by $37.5 \%$ based on the August data as the flow rate of generator hot water goes up to $10 \mathrm{~m}^{3} / \mathrm{h}$. Similarly, it is displayed that the energy saving enhances slightly for the generator hot water flow rate that reaches $6 \mathrm{~m}^{3} / \mathrm{h}$.

(3) The optimal flow rate of hot water is derived based on the trade-off of energy saving and consumption in water pumps. It is exhibited that the optimal collector and generator flow rate are $3.6 \mathrm{~m}^{3} / \mathrm{h}\left(13.33 \mathrm{~kg} /\left(\mathrm{h} \mathrm{m}^{2}\right)\right)$ and $5.2 \mathrm{~m}^{3} / \mathrm{h}\left(19.26 \mathrm{~kg} /\left(\mathrm{h} \mathrm{m}^{2}\right)\right)$, respectively, for the annual operation. The generator hot water flow rate to the collector one approaches 1.44 in the optimal case. Moreover, the peak annual specific energy saving of SASCHCS is $32.73 \mathrm{~kW} \mathrm{~h} / \mathrm{m}^{2}$.

Author Contributions: J.Z. contributed to writing and analysis, Z.L. contributed to conceptualization, Y.J. contributed to editing, Y.X. contributed to validation. All authors have read and agreed to the published version of the manuscript.

Funding: This work is supported by: (1) Natural Science Foundation of Guangdong Province under the contract No. 2018A030313310, (2) Guangzhou Municipal Science and Technology Project under the contract No. 201904010218, (3) State Key Laboratory of Compressor Technology under the contract No. SKL-YSJ201806, and (4) Key Laboratory of Efficient and Clean Energy Utilization of Guangdong Higher Education Institutes under the contract No. KLB10004.

Conflicts of Interest: The authors declare no conflict of interest.

\section{Nomenclature}

$\begin{array}{ll}A & \text { area }\left(\mathrm{m}^{2}\right) \\ A_{c} & \text { the outer surface area of absorber tube }\left(\mathrm{m}^{2}\right) \\ C_{b} & \text { synthetical conductance }\left(\mathrm{W} /\left(\mathrm{m}{ }^{\circ} \mathrm{C}\right)\right) \\ C_{B} & \text { bond conductance }\left(\mathrm{W} /\left(\mathrm{m}{ }^{\circ} \mathrm{C}\right)\right) \\ c_{p} & \text { specific heat }\left(\mathrm{kJ} /\left(\mathrm{kg}{ }^{\circ} \mathrm{C}\right)\right) \\ d & \text { diameter of the } \mathrm{U} \text {-tube }(\mathrm{m}) \\ D & \text { diameter of insulation }(\mathrm{m}) \\ E & \text { compressor work }(\mathrm{kWh}) \\ F & \text { fin efficiency of straight fin } \\ F^{\prime} & \text { collector efficient factor } \\ F_{R} & \text { heat removal factor } \\ h & \text { heat transfer coefficient }\left(\mathrm{W} /\left(\mathrm{m}{ }^{\circ} \mathrm{C}\right)\right), \text { specific enthalpy }(\mathrm{kJ} / \mathrm{kg}) \\ h_{g-a} & \text { convection heat transfer coefficient }\left(\mathrm{W} /\left(\mathrm{m}^{2}{ }^{\circ} \mathrm{C}\right)\right) \\ h_{p-g, r} & \text { radiation heat transfer coefficient }\left(\mathrm{W} /\left(\mathrm{m}^{2}{ }^{\circ} \mathrm{C}\right)\right) \\ h_{p-g, c} & \text { conduction heat transfer coefficient }\left(\mathrm{W} /\left(\mathrm{m}^{2}{ }^{\circ} \mathrm{C}\right)\right) \\ I & \text { solar irradiance }\left(\mathrm{W} / \mathrm{m}^{2}\right) \\ L M T D & \text { logarithmic mean temperature difference }\left({ }^{\circ} \mathrm{C}\right) \\ L_{T} & \text { length of the header pipe per one } \mathrm{U} \text {-tube }(\mathrm{m}) \\ m & \text { mass flow rate }(\mathrm{kg} / \mathrm{s}) \\ Q & \text { heat load }(\mathrm{kW}) \\ s & \text { tot thermal conductance of the installed } \mathrm{UA}\left(\mathrm{kW} /{ }^{\circ} \mathrm{C}\right) \\ t & \text { time } \\ T & \text { temperature }\left({ }^{\circ} \mathrm{C}\right) \\ U A & \text { product of heat transfer coefficient and area }\left(\mathrm{W} /{ }^{\circ} \mathrm{C}\right) \\ U_{e} & \text { edge loss coefficient }\left(\mathrm{W} /\left(\mathrm{m}^{2}{ }^{\circ} \mathrm{C}\right)\right) \\ U_{L} & \text { overall heat loss coefficient }\left(\mathrm{W} /\left(\mathrm{m}^{2}{ }^{\circ} \mathrm{C}\right)\right) \\ U_{t} & \text { heat loss coefficient from absorber tube to ambient } \mathrm{W} /\left(\mathrm{m}^{2}{ }^{\circ} \mathrm{C}\right) \\ V & \text { specific volume of storage tank }\left(\mathrm{m}^{3}\right)\end{array}$




\begin{tabular}{ll}
$\dot{V}_{c}$ & collector hot water flow rate $\left(\mathrm{m}^{3} / \mathrm{h}\right)$ \\
$\dot{V}_{g}$ & generator hot water flow rate $\left(\mathrm{m}^{3} / \mathrm{h}\right)$ \\
$W$ & the circumferential distance between the U-tubes $(\mathrm{m})$ \\
$\Delta t$ & temperature difference $\left({ }^{\circ} \mathrm{C}\right)$ \\
$\Delta \Delta t$ & double difference of temperatures $\left({ }^{\circ} \mathrm{C}\right)$ \\
Greek symbols & \\
$\alpha$ & absorptivity, distribution $U A$ parameter \\
$\eta$ & efficiency \\
$\lambda$ & thermal conductivity $\left(\mathrm{W} / \mathrm{m}^{\circ} \mathrm{C}\right)$ \\
$\pi$ & pi \\
$\rho$ & density $\left(\mathrm{kg} / \mathrm{m}^{3}\right)$ \\
$\tau$ & transmissivity \\
Subscripts & \\
$a$ & ambient \\
as & absorption subsystem \\
$c$ & collector \\
chi & chiller \\
dis & discharge \\
$e$ & evaporator \\
ext & external \\
$f$ & fluid \\
$g$ & generator \\
$i$ & inlet, current time \\
ins & insulation \\
int & internal \\
loss & loss \\
min & minimum \\
$o$ & outlet \\
rated & rated \\
ref & reference \\
$s$ & isentropic \\
save & save \\
suc & \\
st & \\
& storage tank \\
\hline &
\end{tabular}

\section{References}

1. Mohammed, O.W.; Yanling, G. Comprehensive parametric study of a solar absorption refrigeration system to lower its cut in/off temperature. Energies 2017, 10, 1746. [CrossRef]

2. Liu, Y.L.; Wang, R.Z. Performance prediction of a solar/gas driving double effect $\mathrm{LiBr}-\mathrm{H}_{2} \mathrm{O}$ absorption system. Renew. Energy 2004, 29, 1677-1695. [CrossRef]

3. Allouhi, A.; Kousksou, T.; Jamil, A.; Bruel, P.; Mourad, Y.; Zeraouli, Y. Solar driven cooling systems: An updated review. Renew. Sustain. Energy Rev. 2015, 44, 159-181. [CrossRef]

4. Eicker, U.; Pietruschka, D. Design and performance of solar powered absorption cooling systems in office buildings. Energy Build. 2009, 41, 81-91. [CrossRef]

5. Noro, M.; Lazzarin, R.M. Solar cooling between thermal and photovoltaic: An energy and economic comparative study in the Mediterranean conditions. Energy 2014, 73, 453-464. [CrossRef]

6. Jain, V.; Sachdeva, G.; Kachhwaha, S.S. Energy, exergy, economic and environmental (4E) analyses based comparative performance study and optimization of vapor compression-absorption integrated refrigeration system. Energy 2015, 91, 816-832. [CrossRef]

7. Shirazi, A.; Taylor, R.A.; White, S.D.; Morrison, G.L. Transient simulation and parametric study of solar-assisted heating and cooling absorption systems: An energetic, economic and environmental (3E) assessment. Renew. Energy 2016, 86, 955-971. [CrossRef] 
8. Li, Z.; Liu, L.; Jing, Y. Exergoeconomic analysis of solar absorption-subcooled compression hybrid cooling system. Energy Convers. Manag. 2017, 144, 205-216. [CrossRef]

9. Xu, Y.; Jiang, N.; Wang, Q.; Chen, G. Comparative study on the energy performance of two different absorption-compression refrigeration cycles driven by low-grade heat. Appl. Therm. Eng. 2016, 106, 33-41. [CrossRef]

10. Yu, J.; Li, Z.; Chen, E.; Xu, Y.; Chen, H.; Wang, L. Experimental assessment of solar absorption-subcooled compression hybrid cooling system. Sol. Energy 2019, 185, 245-254. [CrossRef]

11. Li, Z.; Liu, L. Economic and environmental study of solar absorption-subcooled compression hybrid cooling system. Int. J. Sustain. Energy 2018, 38, 123-140. [CrossRef]

12. Jing, Y.; Li, Z.; Chen, H.; Lu, S.; Lv, S. Exergoeconomic design criterion of solar absorption-subcooled compression hybrid cooling system based on the variable working conditions. Energy Convers. Manag. 2019, 180, 889-903. [CrossRef]

13. Qu, M.; Yin, H.; Archer, D.H. A solar thermal cooling and heating system for a building: Experimental and model based performance analysis and design. Sol. Energy 2010, 84, 166-182. [CrossRef]

14. Ratlamwala, T.A.H.; Abid, M. Performance analysis of solar assisted multi-effect absorption cooling systems using nanofluids: A comparative analysis. Int. J. Energy Res. 2018, 42, 2901-2915. [CrossRef]

15. Ghoneim, A.A. Performance optimization of evacuated tube collector for solar cooling of a house in hot climate. Int. J. Sustain. Energy 2016, 37, 193-208. [CrossRef]

16. Al-Alili, A.; Islam, M.D.; Kubo, I.; Hwang, Y.; Radermacher, R. Modeling of a solar powered absorption cycle for Abu Dhabi. Appl. Energy 2012, 93, 160-167. [CrossRef]

17. Mazloumi, M.; Naghashzadegan, M.; Javaherdeh, K. Simulation of solar lithium bromide-water absorption cooling system with parabolic trough collector. Energy Convers. Manag. 2008, 49, 2820-2832. [CrossRef]

18. Agrouaz, Y.; Bouhal, T.; Allouhi, A.; Kousksou, T.; Jamil, A.; Zeraouli, Y. Energy and parametric analysis of solar absorption cooling systems in various Moroccan climates. Case Stud. Therm. Eng. 2017, 9, 28-39. [CrossRef]

19. Sokhansefat, T.; Mohammadi, D.; Kasaeian, A.; Mahmoudi, A.R. Simulation and parametric study of a 5-ton solar absorption cooling system in Tehran. Energy Convers. Manag. 2017, 148, 339-351. [CrossRef]

20. Iranmanesh, A.; Mehrabian, M.A. Optimization of a lithium bromide-water solar absorption cooling system with evacuated tube collectors using the genetic algorithm. Energy Build. 2014, 85, 427-435. [CrossRef]

21. Tzivanidis, C.; Bellos, E. The use of parabolic trough collectors for solar cooling-A case study for Athens climate. Case Stud. Therm. Eng. 2016, 8, 403-413. [CrossRef]

22. Li, Z.; Chen, E.; Jing, Y.; Lv, S. Thermodynamic relationship of subcooling power and increase of cooling output in vapour compression chiller. Energy Convers. Manag. 2017, 149, 254-262. [CrossRef]

23. Chen, E.; Li, Z.; Yu, J.; Xu, Y.; Yu, Y. Experimental research of increased cooling output by dedicated subcooling. Appl. Therm. Eng. 2019, 154, 9-17. [CrossRef]

24. Buonomano, A.; Calise, F.; Palombo, A. Solar heating and cooling systems by absorption and adsorption chillers driven by stationary and concentrating photovoltaic/thermal solar collectors: Modelling and simulation. Renew. Sustain. Energy Rev. 2018, 82, 1874-1908. [CrossRef]

25. Ma, L.; Lu, Z.; Zhang, J.; Liang, R. Thermal performance analysis of the glass evacuated tube solar collector with U-tube. Build. Environ. 2010, 45, 1959-1967. [CrossRef]

26. Li, Z.; Yu, J.; Chen, E.; Jing, Y. Off-design modeling and simulation of solar absorption-subcooled compression hybrid cooling system. Appl. Sci. 2018, 8, 2612. [CrossRef]

27. Miao, D. Simulation Model of a Single-Stage Lithium Bromide-Water Absorption Unit; NASA Technical Paper; NASA: Columbia, DC, USA, 1978; p. 1296.

28. Puig-Arnavat, M.; López-Villada, J.; Bruno, J.C.; Coronas, A. Analysis and parameter identification for characteristic equations of single- and double-effect absorption chillers by means of multivariable regression. Int. J. Refrig. 2010, 33, 70-78. [CrossRef]

29. Tchinda, R. Thermal behaviour of solar air heater with compound parabolic concentrator. Energy Convers. Manag. 2008, 49, 529-540. [CrossRef]

30. De ST-. Available online: http://update.dest.com.cn/ (accessed on 12 December 2018).

31. Li, Z.; Ye, X.; Liu, J. Performance analysis of solar air cooled double effect $\mathrm{LiBr} / \mathrm{H}_{2} \mathrm{O}$ absorption cooling system in subtropical city. Energy Convers. Manag. 2014, 85, 302-312. [CrossRef] 
32. Refprop9-. Available online: http://www.nist.gov/srd/nist23.cfm (accessed on 12 December 2018).

33. Nienborg, B.; Dalibard, A.; Schnabel, L.; Eicker, U. Approaches for the optimized control of solar thermally driven cooling systems. Appl. Energy 2017, 185, 732-744. [CrossRef]

(c)

(C) 2020 by the authors. Licensee MDPI, Basel, Switzerland. This article is an open access article distributed under the terms and conditions of the Creative Commons Attribution (CC BY) license (http://creativecommons.org/licenses/by/4.0/). 